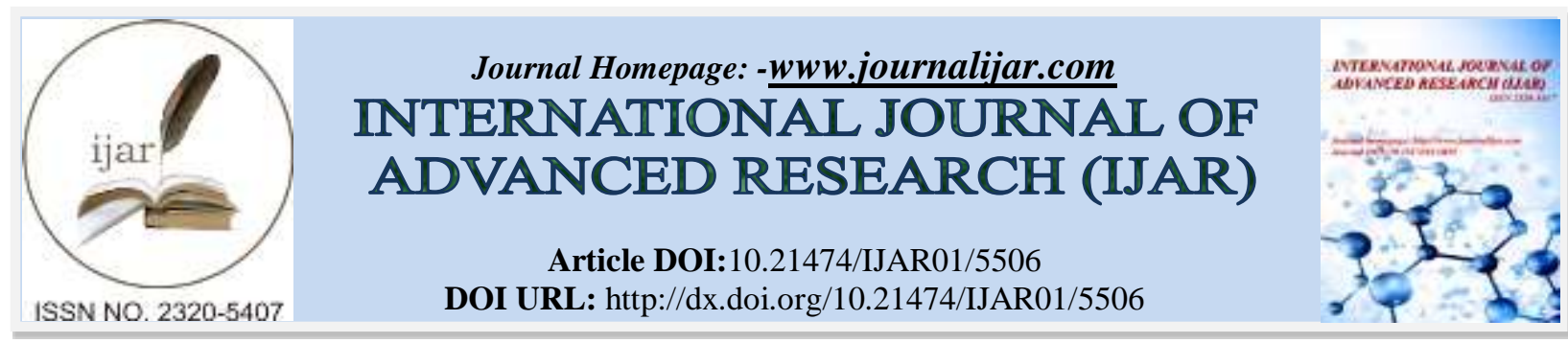

RESEARCH ARTICLE

\title{
THE EFFECT OF E-SERVICE QUALITYON THE SATISFACTION THROUGH PERCEIVED VALUE ON WEB-BASED ACADEMIC SERVICES.
}

Sukaris, Budiyono Pristyadi.

Departement of Management, FEB, Muhammadiyah University, Gresik.

\section{Manuscript Info}

Manuscript History

Received: 01 August 2017

Final Accepted: 03 September 2017

Published: October 2017

Key words:-

e-Service Quality, Value, Customer

Satisfaction, Information Systems.

\begin{abstract}
At the moment, the service delivery system of a university is not only tangible but also intangible. For a college to succeed in the long run, it must create services that satisfy the needs and wants of its users. The use of information technology in higher education applications has changed not only the nature of the service itself but also the process of service delivery to provide quality service in meeting the needs of students, creating value that will eventually create satisfaction. Thus eservice quality has a strong influence on customer perceived value, and there is also a positive relationship between customer perceived value and customer satisfaction. The purpose of this study is to determine the effect of e-service quality toward satisfaction through perceived value on web-based academic services. The analysis technique used in this research was path analysis. Confirmatory factor analysis techniques were used to test the instrument. The results showed that by confirmatory factor analysis, all the instruments used in this study were valid and reliable. The test shows a positive and significant effect of the variable of e-service quality on perceived value, e-service quality on student satisfaction, perceived value influence on student satisfaction, and e-service quality effect on student satisfaction through perceived value.
\end{abstract}

Copy Right, IJAR, 2017,. All rights reserved.

\section{Introduction:-}

The service delivery system of a university at present is not only tangible but also intangible. These intangible services are even more perceived with the advance of information technology which colleges use as a form of support for users, whether internal or external, which in this case consist of students.

This service delivery process that is supported by information technology is usually referred to as a web-based (or Internet-based) information system. At present, web sites are one of the most frequently used sources of information. As a form of an application, web sites are made with the purpose that users can interact with information providers (service providers) quickly and easily through the Internet. Web applications are also able to provide dynamic information with database connections. Such information systems themselves are inseparable from physical (offline) services such as services by staff, employees, lecturers, or other human resources. For a college to succeed in the long run, it must create services that satisfy the needs and wants of its users. This service delivery process plays a significant role in supporting the success of marketing educational services and providing 
satisfaction to its users (Alma 2007; 12).

Research had shown that less than two percent of online visits concluded with product purchase (Bellman, 2001) and that bad quality of services contribute to more or less $80 \%$ of customer complaints toward e-retailers (Dobie et al., 2001); in addition, there is a tendency that consumers prefer to seek product and price information online but still shop in offline markets due to concerns of security and privacy in shopping online (Tjiptono 2007; 291). The use of information technology in college applications has not only changed the nature of the service itself but also has changed the process of service delivery to be able to provide a quality of service that fulfills the needs of students and creates value for them, which in the end will create satisfaction. This is in line with research by Chinomonaet al. (2014)who found that e-service quality has a strong influence on the value perceived by users and also that there was a positive relationship between perceived customer value and customer satisfaction.

Electronic service quality (e-service quality) is the quality of electronic services or web-based services. Zeithamlet al. (2002) defines electronic service quality (e-service quality) as how far a web site can effectively and efficiently facilitate shopping, purchase, and delivery of products and services. In the context of e-service quality for an education information system, the information system must be able to effectively and efficiently facilitate academic activities and deliver academic products to students. E-service qualitywill be able to affect the perceived value and satisfaction of students if the e-service has such features as availability of information, completeness of contents, ease of use, security or privacy, graphical appeal, and fulfillment or reliability.

Customer satisfaction is affected not only by the quality of services, whether online or offline, but also by the value that users obtain with their expenses. This value is the overall judgment of the consumer from the use of a product based on the perception of what has been received and what has been given. Value in the context of web-based information systems is functional and emotional in nature. The functional value of a web site is the ability or performance of the site in carrying out its functions. Meanwhile, the emotional value is the positive feeling from the use of a (web) product. It can then be assumed that web-based information systems will be able to affect the satisfaction of students if it possesses a standard of quality, functions consistently, creates the desire for reuse, and creates a happy impression for the web site itself.

The variable of customer satisfaction is the final part of the process of purchase and selection of products or services; in addition to trust and loyalty, the creation of satisfaction of web-based users requires a long struggle, but once customer satisfaction has been created there will be many benefits that an institution will receive, such as among others online comfort, trust, security, customization, utility, ease, price effectiveness of price, and perceived value.

Based on the above, it becomes important to conduct this research, because in academic systems, measurement of electronic services is very rarely performed and several other researches only examined online shops, e-retailers, and in general web sites (portals) as research objects. Even so, this research also uses quality indicator variables that are adapted from online shops, e-retailers, and web sites, aswell as the character of e-service quality in education information as the object of comparison. Based on the presented problem, the formulated research objectives includes: to understand the effect of e-service quality on the value perceived by students, to understand the effect of e-service quality on student satisfaction, to understand the effect of perceived value on student satisfaction, and to understand the effect of e-service quality on student satisfaction through perceived value.

\section{Literature Review:-}

Academic Information Systems:-

An information system is defined as a collection of components that are interrelated to collect or to obtain, process, store, and distribute information to support the making of decisions and supervision in an organization (Laudon and Laudon 2015; 16). Karuniawan (2004; 1) states that a management information system (MIS) is a structured system that is used to manage data in a computerized manner; within a MIS there are functions that companies need, such as data searching, periodical updating of data, presentation of data to the public, and data storage.

Further development of the use of this system is its adjustment to usage and needs, such as management information systems, marketing information systems, accounting information systems, and so on, including academic information systems which are used for academic activities. These academic activities cover course schedules, 
course selection data entry, course report card viewing, lecturer data, and student registration, as well as academic supervision.

Academic information systems are the primary access to organize all collegiate affairs and other things related to academics (Setiawan 2013). This system is usually utilized in academic environments for the learning and teaching process or related matters in both schools and collegiate institutions; for colleges this system is one of the services for students, staff, lecturers, suppliers, and other stakeholders in the effort to increase service performance. Academic information systems are compiled from a variety of data that are managed and processed as automatically as possible with tools and methods to produce information needed to carry out academic activities. These systems are divided into several sub-systems: (a) selection and registration of new students; (b) curricula and majors; (c) courses, assignments, exams; (d) lecturer management and development; and (e) passing, graduation, alumni (Indrayani 2011)

Academic information systems in colleges are created not only to follow trends and formation of public opinion but also to provide several benefits both for the college itself and its users, particularly the students.

Aswatiet al. (2015) state that several benefits of the use of academic information systems include:

1. Cost reduction

2. Error reduction

3. Increase in the pace of activities

4. Increase of management planning and control

Further, the benefits of information systems can be stated in the form of tangible benefits and intangible benefits, which include:

1. Tangible benefits among others:

a. Reduced operational costs

b. Reduced errors of telecommunication

2. Intangible benefits:

a. Improvement in services

b. Improvement in personal satisfaction of work

c. Improvement in making decisions

The information system in Muhammadiyah University at Gresik (UMG), abbreviated as siakad as in the URL www.siakad.umg.ac.id is a system that represents the concern of UMG to apply information technology in increasing management quality. This system focuses on administrative affairs of students including re-registration, supervision, and transcript and diploma printouts in an automatic and rapid manner (Anonymous, 2014; 22).

\section{Electronic Service Quality (E-Service Quality):-}

Defining the quality of electronic services (e-service quality) can be done by associating the definition of the service quality itself because the web site is also the entity of a product. Thus in the research the definition of e-service quality is adapted from the quality of the service in general.

Zeithamlet al. (2002) defines electronic service quality (e-service quality) as how far a web site can effectively and efficiently facilitate shopping, purchase, and delivery of products and services. Further, Zeithamlet al. provides the dimensions of e-service qualitymeasurement to include:

1. Information availability and content

2. Ease of use

3. Security

4. Graphic style

5. Fulfillment or reliability

Tjiptono $(2007 ; 291)$ summarizes the dimensions of e-service qualityfrom exploring several researches:

1. Dabholkar (1996) identifies five factors, namely, the speed of delivery, ease of use, reliability, enjoyment, and control.

2. Szymanski and Hise (2000) presents four determinant factors of e-satisfaction, namely, online comfort, product information, site design, and financial security. 
3. Zeithamlet al. (2000) presents eleven dimensions of electronic service quality, namely, access, ease of navigation, efficiency, flexibility, reliability, personalization, security/privacy, response capability, trust/faith, site aesthetics, and price knowledge.

4. Kaynama and Black (2000) put forward seven dimensions, namely, content, access, navigation, design, response, background, and personalization.

5. Lociaconoet al. (2000), quoted in Zeithamlet al. (2002), develops the WEBQUAL scale, which is composed of 12 dimensions, namely, the appropriateness of information for the task, interaction, trust, response time, design, intuitiveness, visual appeal, innovative appeal, emotional appeal, communication integration, business process, and substitutability.

6. Yoo and Donthu (2001) formulated four basic SITEQUAL dimensions, namely, the ease of use, aesthetic design, processing speed, and security.

7. Lijanderet al. (2002) proposed four dimensions of e-quality, which cover site design and content, trust, empathy, and security.

\section{Customer Value:-}

Value is the measure of what has been obtained from expenses and may also be stated as the difference between benefit and costs. The organization should strive as greatly as possible to create products or services that are able to provide value for customers. As stated by Kotler and Amstrong (2004), "customer value is the difference between the values the customer gains from owning and using a product and the cost of obtaining the product".

Kotler and Keller (2009) define customer perceived value as being the difference in the evaluation of a prospective customer over all benefits and costs of an offer toward its alternatives, and total customer benefit as the monetary value of the set of economic, functional, and psychological benefits that a customer expects from a market offer caused by products, personnel, and involved images.

There are other definitions, such as by Çetinsöz (2015), who holds that "Perceived value is defined as 'the total evaluation of the benefits of a product by the customer about what was purchased and what was received in terms of goods or services' (Wood and Heerden, 2007)." "Many studies have shown that customer value is the link between online purchase/repurchase and perceived e-service quality." (Bressolles and Durrieu, 2011; Chang and Wang, 2008; Zeithaml, Parasuraman and Malhotra, 2002) "In a study carried out by Zeithaml (1988) value was defined as 'quality received for payment'. As a result of the evaluation of the benefits perceived by the consumer and the perceived costs regarding a product/service a perceived value is established in the mind of the consumer regarding the relevant product/service." (Dursun and Çerçi, 2004)

Customer value is the positive function from what is received and the negative function of what the consumer sacrifices (Oliver, in Widjaya (2009)).

\section{Customer Satisfaction:-}

Triyono $(2006$; 152) states that "customers can be considered satisfied if their expectations are fulfilled or exceeded". This can be depicted further in the customer satisfaction cycle. 


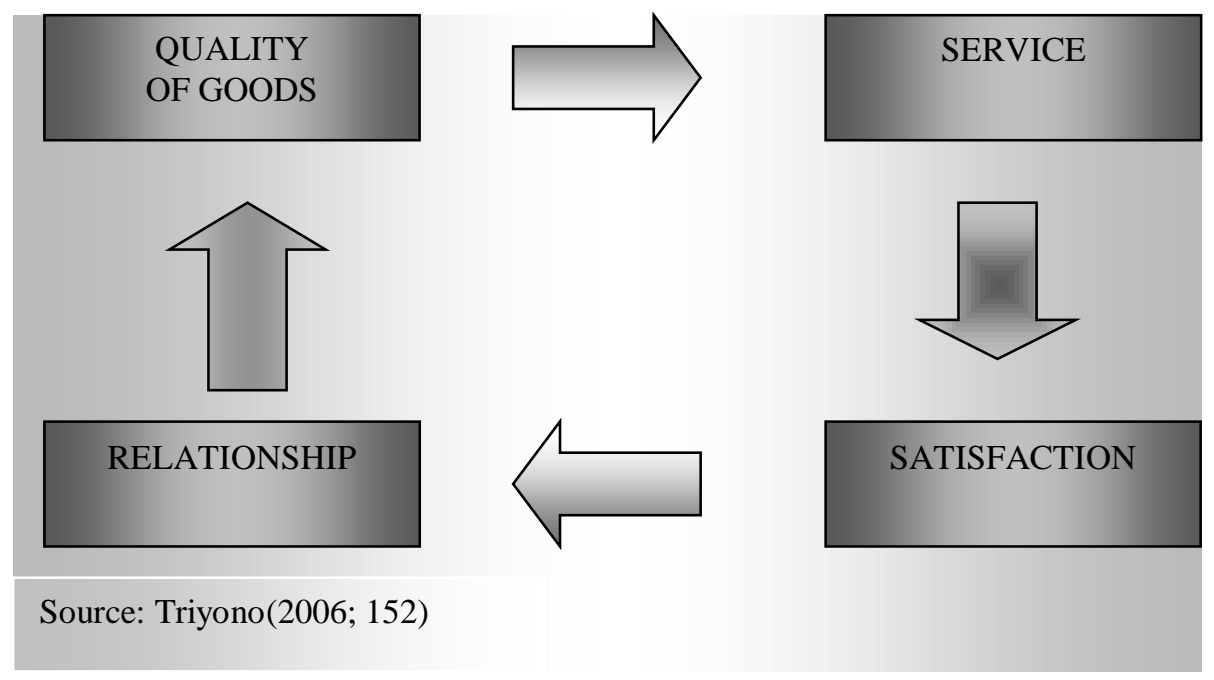

Figure 1:- Customer Satisfaction Cycle

From the figure above it can be seen that the quality of goods and services will create satisfaction and satisfaction in turn creates relationships. Tjiptono (2007) explains that basically the understanding of "customer satisfaction covers differences between expectations and performance or perceived results". Tjiptono and Diana $(2001 ; 102)$ state that customer satisfaction is a "response of customers toward the evaluation of incompatibility perceived between prior hopes or other performance norms and the actual product performance perceived after its use". Chandra $(2002 ; 6)$ explains that the "customer satisfaction rate toward a particular product is the result of a comparison that the customer performs on the level of benefits that have been perceived to have been received after consumption or use of the product and the level of benefits that was expected before purchase".

Many other definitions were stated by experts quoted by Tjiptono (2000; 146), including:

1. Day (1988), who states that satisfaction or dissatisfaction of a customer is the response of the customer toward the evaluation of incompatibility/disconfirmation that is felt between prior expectations and the actual performance felt after use;

2. Engel et al. (1990), who states that customer satisfaction is the post-sale evaluation where the chosen alternative at the least provides the same results as or exceeds the expectation of the customer, while dissatisfaction arises if the obtained results did not fulfill customer expectations;

3. Kotler (1994), who asserted that customer satisfaction is the level of satisfaction of someone after comparing performance (or results) that is felt compared to expectations.

From the understandings of customer satisfaction above, it can be concluded that customer satisfaction is the fulfillment of needs according to or exceeding the expectations of consumers. As such, every company must examine the gap between what customers expect with the results that they perceive.

\section{Research Hypothesis:-}

Based on the conceptual framework, these research hypotheses are formulated:

1. E-service quality affects the value perceived by students.

2. E-service quality affects the satisfaction of students.

3. Perceived value affects the satisfaction of students.

4. E-service quality affects the satisfaction of students through perceived value.

\section{Research Methods:-}

Research Model:

The research model developed in this research is as presented in the following figure: 


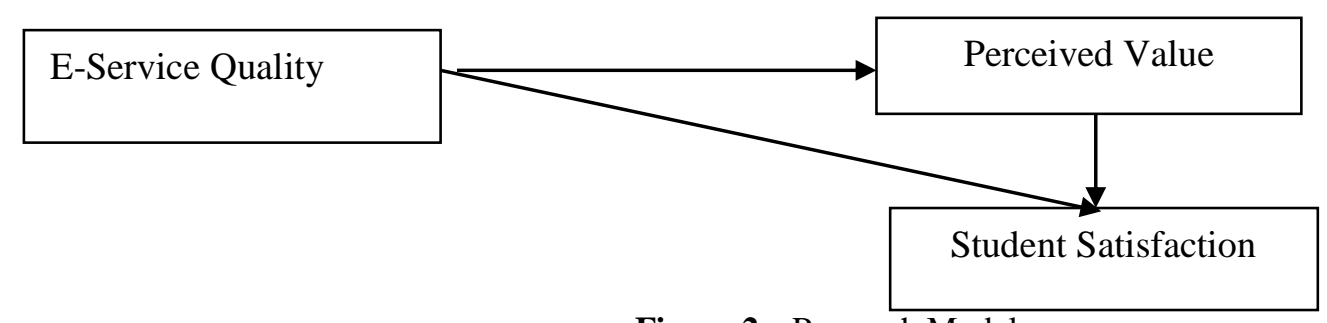

\section{Research Design:-}

Figure 2:- Research Model

This research used the quantitative approach because with this approach the research process can be conducted in a structured manner using research samples. The population in this research was determined to be students of the Management Study Program. The number of samples was determined to be 200 students according to the basic assumption of the minimum number for structural equation modeling (SEM); this assumption is an established condition for the model, which was used as the analytical tool for the research. The use of this model necessitates the selection of at least 100 samples (Ferdinand; 2006), and according to Ghozali (2006:21) the method of Maximum Likelihood needs at least 100 samples. When the sample size is greater than 100 , the method of Maximum Likelihood increases in sensitivity in detecting differences among data. With a large sample size, the ML method becomes very sensitive and always results in significant differences, decreasing the quality of the goodness of fit. Thus it is recommended that a sample size from 100 to 200 be used for the Maximum Likelihood estimation method to be effective. Hence, this research used 200 samples. The sample collection technique was proportional random sampling in the first stage of morning- and afternoon-class students (regardless of their entry years) while in the second stage the technique of accidental sampling is used to determine to whom the research instrument is given.

\section{Data Types and Sources:-}

The data sources used in this research include primary data obtained from questionnaire results of users of siakad.umg.ac.id, and as the questionnaire was created using a semantic differential scale, the collected data is accordingly interval data (Emory and Cooper, 1996). Secondary data used in this research are background and supporting data taken from journals, literature, and other references.

\section{Instrument Testing:-}

To test the accuracy of and trust in the research instrument, a validity and reliability test was conducted. The validity and reliability used in this research is the Confirmatory Factor Analysis (CFA) technique with the aid of LISREL 8.80; the standard used was a critical t-value > 1.96, where if the $\mathrm{t}$-value was greater than 1.96 , the instrument used is valid and reliable.

\section{Data Analysis:-}

In order to achieve the research objectives, test the relationships among variables, and evaluate the composed research model, data analysis was conducted with the path analysis technique using the aid of the LISREL software program.

These are the equations for the path analysis model:

1. Equation 1: $Z_{1}=a+b_{1} X+e$

2. Equation 2: $Y=a+b_{1} X+b_{2} Z+b_{3} X * Z+e$

In the research, evaluation of the structural equations utilized the values that were available in the results of estimation values, whether direct or indirect.

\section{Hypothesis:-}

To test the hypotheses presented in section 2, the t-test was used, with the decision criteria for the hypothesis being accepted if the $\mathrm{t}$-count is greater than the $\mathrm{t}$-value of 1.96, with a significance level of $5 \%$.

\section{Results and Discussion:-}

The likelihood ratio of the chi-square statistic is the fundamental measure of the overall fit. A high chi-square value in regard to the degree of freedom shows that the covariant matrix or correlation that is observed with what is predicted is actually different, and this results in a smaller probability than the rate of significance $(\alpha)$. In this 
research, the evaluation criteria for the goodness of fit statistics consists of the following: Degrees of Freedom $=0$, Minimum Fit Function Chi-Square $=0.0(\mathrm{P}=1.00)$, Normal Theory Weighted Least Squares Chi-Square $=0.00(\mathrm{P}$ $=1.00)$; the model is saturated, and the fit is perfect, and thus it can be concluded that the model used in this research has a fit.

\section{Hypothesis Testing:-}

After testing was carried out on the research model, the next step was to test the causality of the hypotheses developed in the research model. From the fitting model, each path coefficient could be interpreted. The path coefficients are presented in details in Table 1 and Figure 3.

Table 1: Hypothesis Testing Results

Figure 3: t-Values and Estimation Coefficient Values

Based on Table 1 and Figure 2, the interpretation for each path coefficient is as follows:

1. Hypothesis 1 (H1) - e-service quality affects perceived value (customer value) by students: Table 1 shows that e-service quality had a significant effect on value perceived by students (customer value). This is evident from the path coefficient of 0.49 with a positive sign and a t-value of 12.69 , greater than the critical value of 1.96 at a significance level of 0.05 . These results support the first hypothesis of the research that e-service quality affects the value perceived by students (customer value) after accessing the siakad.umg.ac.id web site.

2. Hypothesis $2(\mathrm{H} 2)$ - e-service quality affects student satisfaction (e-customer satisfaction): Table 1 shows that e-service quality had a significant effect on student satisfaction (e-customer satisfaction).This is evident from the path coefficient of 0.15 with a positive sign and a t-value of 2.15 , greater than the critical value of 1.96 at a significance level of 0.05 . These results support the second hypothesis of the research that e-service quality affects the student satisfaction (e-customer satisfaction).

3. Hypothesis $3(\mathrm{H} 3)$ - perceived value (customer value) by students affects student satisfaction (e-customer satisfaction): Table 1 shows that value perceived by students (customer value)affected student satisfaction (ecustomer satisfaction). This is evident from the path coefficient of 0.85 with a positive sign and a $t$-value of 2.15, greater than the critical value of 1.96 at a significance level of 0.05 . These results support the third hypothesis of the research, i.e. that the value perceived by students (customer value) after accessing the web site affects the student satisfaction (e-customer satisfaction).

4. Hypothesis $4(\mathrm{H} 4)$ - e-service quality affects student satisfaction (e-customer satisfaction) through value perceived by students (customer value): Table 1 shows that e-service quality affected student satisfaction (ecustomer satisfaction) and the value perceived by students(customer value).This is evident from the path coefficient of 0.82 with a positive sign and a t-value of 7.36, greater than the critical value of 1.96 at a significance level of 0.05 . These results support the fourth hypothesis of the research that e-service quality affects student satisfaction (e-customer satisfaction) through the value perceived by students (customer value).

\section{Discussion of Research Results:-}

5. Based on the evaluation of respondents to all indicator variables of the research results, the researcher discovered that most respondents gave a good evaluation.Even so, the descriptions for the indicators of the research variables only informed how high or low students evaluated the indicator variables of the research. This information was able to answer the research questions and provide explanations on the structured relationships or effects that are created among the three research variables. The research questions were answered by the results of path analysis using LISREL 8.80 .

6. The test on the models (measuring model and structural model) created for this research (by evaluating the suitability of the model with the data) resulted in a feasible level of suitability and thus the created model was feasible and perfect to be used to test the research hypotheses and to obtain its results. The results of the hypothesis testing conducted in the previous section are discussed in this section.Four hypotheses were tested in this research, and three of them proved to create significant effects.

\section{The Effect of E-Service Quality on the Value Perceived by Students (Customer Value):-}

The quality of electronic services for an academic information system necessitates that the information system must be able to effectively and efficiently facilitate academic activities and deliver academic products to students. Based on the study, the academic information system web site being studied provided the necessary academic information. The information that the system provided could be easily recognized, the web site was easy to use, the site had an attractive appearance, and there was no difficulty in accessing the website, which otherwise would affect the value perceived by students (customer value). In other words, as the siakad.umg.ac.id web site becomes more able to fulfill academic needs, more able to show information recognizably, easier to operate, more attractive in appearance, 
and easier to access, the value that students perceive becomes higher. Table 1 shows that the e-service quality had a significant effect on the value perceived by students after accessing the web site. This can be seen from the path coefficient which has a positive sign with a t-value of 12.69 , greater than 1.96. This result supports the first hypothesis of the research that e-service quality significantly affects the value perceived by students. The results of this research supports the theory of Zeithamlet al. (2002) who define e-service quality as how far a site can effectively and efficiently facilitate shopping, purchase, and delivery of products and services. With regards to an academic information system, to be considered of high quality, an academic information system must be able to effectively and efficiently facilitate academic activities and deliver academic products to students. This research is also in line with prior research by Çetinsöz (2015) one-service quality influence oncustomer perceived value of domestic tourists in Turkey. In that, the results showed that e-service quality had a significant contribution to the perceived value of domestic tourists regarding the products that they buy online.

\section{The Effect of E-Service Quality on Student Satisfaction (E-Customer Satisfaction):-}

The quality of electronic services for an academic information system necessitates that the information system must be able to effectively and efficiently facilitate academic activities and deliver academic products to students. With regards to the academic information system web site that the researcher studied, the site provided the necessary academic information, the information provided was easily recognizable, the web site was easy to use, the site had an attractive appearance, and there was no difficulty in accessing the website that affected the perceived value (customer value) by students. In other words, as the siakad.umg.ac.id web site becomes more able to fulfill academic needs, more able to show information recognizably, easier to operate, more attractive in appearance, and easier to access, the satisfaction that students feel increases. Table 1 shows that the e-service quality had a significant effect on student satisfaction (e-customer satisfaction). This is evident from the path coefficient which has a positive sign with a t-value of 2.15, greater than1.96. Thus this result supports the second hypothesis of the research that e-service quality affects significantly student satisfaction (e-customer satisfaction). The results of this research supports the research conducted by Ndori (2015) on the effect of the academic information system and service quality on student satisfaction at the Semarang Polytechnic of Navigation, in which it was found that the most influential free variable on student satisfaction was the variable of academic information system with coefficient of 0.550 .

\section{The Effect of the Value Perceived by Students(Customer Value) on Student Satisfaction (E-Customer Satisfaction):-}

Value in the context of web-based information systems is a value that is functional (by performance) and emotional in nature. The functional value of a web site is the capability of the web in running its functions. On the other hand, emotional value is the positive feeling that results from the use of the web product. Hence it can be assumed that a web-based academic information system can affect student satisfaction if it has quality standards, functions consistently, incites the desire to use it again, and creates a happy feeling toward the web site itself. The evaluation by students covers the evaluation of the academic information system that looks for these characteristics. In other words, the greater the perceived value or the more benefits obtained from the web site, the greater student satisfaction (e-customer satisfaction) will be; students will feel more comfortable with supervisory activities on the site, become more confident using the site, feel safer conducting activities on the site, feel satisfied with available features on the site, sense the meaning of the site, and ultimately have the desire to reuse the site at a later time. Table 1 shows that the value perceived by students after accessing the web site affected student satisfaction (ecustomer satisfaction). This can be seen from the path coefficient, which has a positive sign with a t-value of 9.03, greater than 1.96. This result supports the third hypothesis of this research which states that perceived value by students has an effect on student satisfaction (e-customer satisfaction). The results of this study supports prior research conducted by Prabandari (2015) which examined e-service quality, perceived value, and customer satisfaction on customer loyalty in online shopping through zalora.co.id. The results of that research led to the conclusion that the value perceived by customers affected customer satisfaction significantly.

The Effect of E-Service Quality on Student Satisfaction (E-Customer Satisfaction) Through the Value Perceived by Students (Customer Value):-

Table 1 shows that e-service quality affects student satisfaction (e-customer satisfaction) and the value perceived by students(customer value).This is evident from the path coefficient of 0.82 which has a positive sign with a t-value of 7.36 and greater than the critical value of 1.96 at a significance rate of 0.05 . This result supports the fourth hypothesis of this research that e-service quality affects student satisfaction (e-customer satisfaction) through the perceived value (customer value) by students. The results of this study supports prior research conducted by Prabandari (2015) which examined e-service quality, perceived value, and customer satisfaction on customer loyalty 
in online shopping through zalora.co.id. The results of that research led to the conclusion that (1) e-service quality significantly affected customer loyalty; (2) e-service quality significantly affected customer satisfaction; (3) eservice quality significantly affects the value perceived by customers; (4) the value perceived by customers significantly affected customer satisfaction; (5) the value perceived by customers did not affect customer loyalty; and (6) customer satisfaction significantly affected customer loyalty. This research also supports the research by Chinomonaet al. (2014)which found that e-service quality had a strong influence on perceived value by customers and that there was also a positive relationship between perceived value by customers and customer satisfaction.

\section{Research Limitations:-}

Based on the analysis results and its discussion, the researcher realizes that this research has not been able to provide truly accurate results. There are several limitations for this research:

1. This research only takes the setting of a single college, so it has limits for the generalization of its results for colleges in general, with respect to the character of the college or additional comparisons of offline and electronic services.

2. The observable variables were still found to be unreliable.

3. As much as possible, the data collection should use random sampling.

\section{Conclusion:-}

The conclusion from the research results is that the variable of e-service quality has an effect on the value perceived by students, the variable of e-service quality has an effect on student satisfaction, and the variable of perceived value has an effect on student satisfaction; additionally e-service quality has an effect on student satisfaction through perceived value.

The results of the research may present a chance for managerial practices and future research agendas. For managerial practices to achieve web site user satisfaction (e-customer satisfaction) in particular for academic web sites, there needs to be improvement and increase in web site performance so that it may fulfill or even surpass user expectations (value), including by making the website more attractive and easier to navigate. Future research may also compare the level of satisfaction between the use of electronic and that of manual (offline) academic services and compare academic services across colleges and the e-services of establishments other than colleges.

\section{References:-}

1. Alma, Buchori, 2007, ManajemenBisnisBerbasisPenelitian, Alfabeta, Bandung.

2. Anonim, 2014, BukupanduanAkademikUniversitasMuhammadiyah Gresik

3. Aswati, dkk, 2014, peranan sistem informasi bagi perguruan tinggi, jurnal teknologi dan sistem informasi, vol 1 no 2 hal $79-86$.

4. Cetinzos, Cevdet, Burzin, 2015, The Influence of E-Service Quality on Customer Perceived Value: A Study on Domestics Tourists in Turkey, International Journal of Science and Research (IJSR), Volume 4 Issue 1, January 2015.

5. Chinonoma et al, 2014, The Influence of E-Service Quality on Customer erceivedValue,Customer Satisfaction and Loyalty in South Africa, Mediterranean Journal of Social Sciences, MCSER Publishing, Rome-Italy, Vol 5 No 9 .

6. [6] Chandra, Gregorius, 2002, Strategi dan Program Pemasaran, PT. Andi, Yoyakarta.

7. Cooper dan P. S Schindler, 1996, Business Research Methods, 8 ed., McGraw-Hill/Irwin, New York.

8. Ferdinand, Augusty, 2006,Structural Equation Modelling Dalam Penelitian Manajemen, Edisi Empat. Semarang, Badan Penerbit Universitas Diponegoro.

9. Ghozali, Imam, 2006. Model Persamaan Struktural; Konsep dan Aplikasi dengan Program AMOS 5.0. Edisi Kedua. Semarang: Badan Penerbit Universitas Diponegoro.

10. Indrayani, Etin,2011, PengelolaanSistemInformasiAkademikPerguruanTinggiBerbasisTeknologiInformasi Dan Komunikasi (Tik)JurnalPenelitianPendidikan Vol. 12 No. 1, April 2011

11. Kurniawan, 2004, SistemInformasiManajemendengan Visual Basic, PenerbitAndi Yogyakarta.

12. Kotler, Philip.,, 2002, Manajemen Pemasaran, Edisi Millenium, Prehallindo, Jakarta.

13. ............, and Amstrong, Gery, 2004, Principles of Marketing, Tenth Edition, Pearson Prentice Hall, New Jersey.

14. ..........., and lane Keller, 2009, Marketing Management, Twenth Edition, Pearson Prentice Hall, New Jersey.

15. Laudon ,C Kenneth dan Laudon P.Jane, 2015, Sistem Informasi Manajemen, mengelola perusahaan digital, Penerbit Salemba Empat, Jakarta. 
16. Ndori, Akhmad, 2015, PengaruhSistemInformasiAkademik Dan KualitasLayananTerhadapKepuasanMahasiswa Di PoliteknikIlmuPelayaran Semarang J. Sain Dan Tek. Maritim Vol. Xiii No.2, 2015.

17. Oliver, R.L. ,1999, "Whence Customer Loyalty?,” Journal of Marketing, Vol. 63, Special Issue.

18. Prabandari, Dian Ajeng 2015, Analisis Electronic Service Quality (E-Service Quality), Nilai Yang Dirasakan, Dan KepuasanKonsumenPadaLoyalitasKonsumenDalamPembelian Online Melalui Zalora.co.id, http//:eprints.uns.ac.id/18699/, $\quad$ diaksestanggal $\quad 27 \quad 2016$

19. Setiawan, Alexander dkk. 2013. PembuatanAplikasiSistemInformasiAkademik Di SekolahTinggiThelogia Semarang, Seminar NasionalInformatika 2013.

20. Tjiptono, Fandy, 2000, Total QualityService, EdisiRevisi, Andi, Yogyakarta.

21. ........., dan Anastasia Diana, 2001, Total Quality Management, EdisiRevisi, Andi, Yogyakarta.

22. ............ 2007, Strategi Pemasaran jasa, Edisi Keempat, Andi, Yogyakarta.

23. Triyono, Sigit, 2006, SuksesTerpaduBisnisRitel, Edisipertama, PT. Elex Media Komputindo, Jakarta.

24. Widjaya, Bernard T , 2009, Lifestyle Marketing, Gramedia Pustaka Utama, Jakarta.

25. Zeithaml, V.A, A. Parasuraman dan A. Malhotra,2002,“A Conceptual Framework for UnderstandingE-service Quality: Implications for Future Research and Managerial Practice," Working Paper, Report Nr.00 - 115 (Cambridge, MA, Marketing Science Institute). 